\title{
Cenários de aliciamento na rede
}

\section{Marta Brites Rosa}
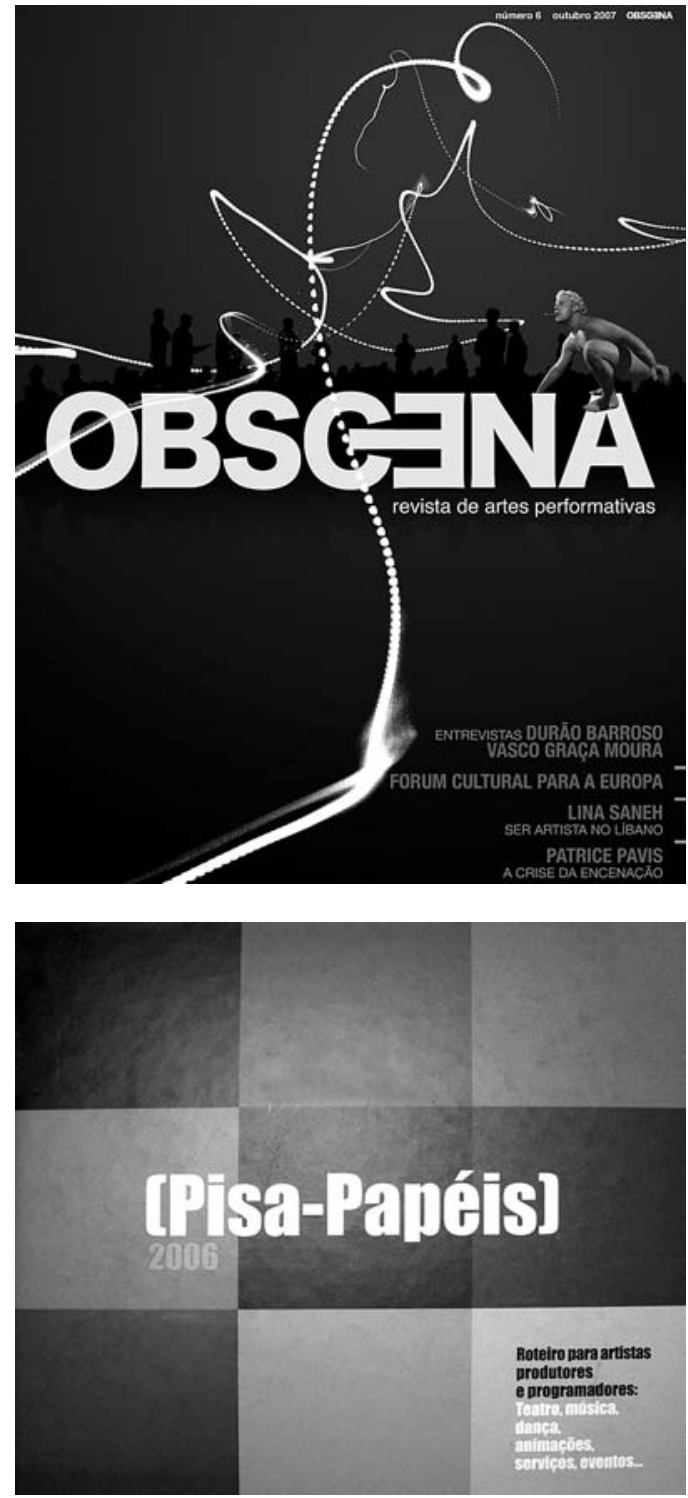

O Melhor Anjo (www.omelhoranjo.blogspot.com) é o blogue mantido por Tiago Bartolomeu Costa, produtor, crítico, investigador e editor da revista Obscena.

Iniciado em 2003, tem vindo alterar o seu conteúdo - como o próprio autor afirma: "deixou de ser um espaço para observações sobre o quotidiano, para se tornar num espaço de reflexão", transformando-se um ponto de referência do pensamento sobre as artes performativas e a crítica.

A leitura do blogue é aliciante, pois além de uma grande variedade de assuntos, as muitas hiperligações existentes em todos os artigos permitem-nos navegar ad aeternum tanto dentro do próprio blogue, como fora. Cada artigo revela um mundo novo, que somos levados a descobrir pelo clicar constante em páginas electrónicas, que nos conduzem a realidades que não conheciamos bem ou que desconheciamos de todo. E desta forma, a linguagem, por vezes um pouco obscura, torna-se mais compreensivel e o discurso inicialmente hermético é de repente a chave para um novo prazer a descobrir.

Como a generalidade dos blogues, O Melhor Anjo apresenta uma extensa lista de ligações internas e externas, entre as quais se encontra a da revista Obscena (descarregável gratuitamente em formato pdf).

A Obscena aborda igualmente o mundo das artes e da crítica. A nivel gráfico é cativante, com excelentes imagens que partilham com o texto o protagonismo sobre o assunto. Infelizmente, o facto de a versão em papel depender da impressora de cada um leva-me a crer que poucos possam desfrutar a qualidade que aparenta nos monitores de computador.

0 [Pisa-papéis], como objecto físico, assume-se como um "roteiro para artistas, produtores e programadores" e www.pisa-papeis.com é o seu sítio electrónico. Aqui, além de encontrarmos noticias culturais, colocarmos e vermos anúncios na área artística, podemos realizar pesquisas nos seguintes campos: teatro, dança, música, pluridisciplinares, áreas criativas complementares, artes circenses, animadores, infantil, estado, organizações, serviços, espaços, festivais,
Capa da revista Obscena n. 6 Out. 2007 (design Triplinfinito).

[Pisa-papéis] na versăo impresssa.

Marta Brites Rosa é colaboradora do Centro de Estudos de Teatro na implementação da CETbase. 


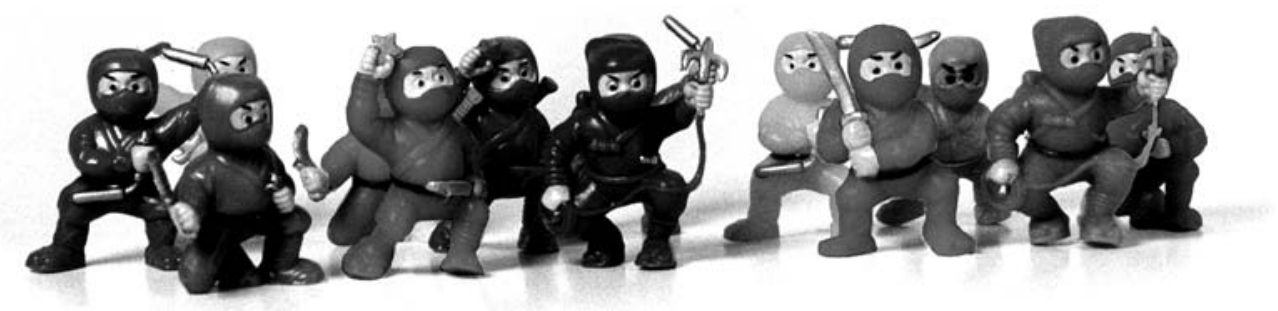

narração oral e formação.

A pesquisa pode ser feita com restrição no campo, introduzindo ou não uma palavra-chave. Assim, acedemos a uma lista de tudo quanto se apresenta sob esse domínio, podendo escolher um titulo e dai partir para uma outra página onde temos acesso a uma imagem, um texto de apresentação e dados relevantes sobre o item escolhido.

A Lab, uma recente inovação do Pisa-papéis e acessivel através do seu portal, é uma publicação temática que se assume como "um espaço de debate e análise aprofundada dos temas estruturais da cultura em geral e das artes em particular" e cujo primeiro número, de Junho '07, é dedicado à "Economia e Cultura".

Graficamente a Lab é semelhante ao Pisa-papéis: páginas limpas, brancas, com boas imagens e de fácil leitura. Na página inicial temos o índice de acesso às várias secções: editorial, entrevistas, reportagens, opinião, fotoreportagem. Pode dizer-se que o Pisa-papéis e a Lab se complementam, já que um fornece os dados, sobre os quais o outro se debruça.

Das muitas companhias do teatro na rede, duas já se materializaram em palcos portugueses: Teatro Akhe e o Tiny Ninja Theater.

A página do Teatro Akhe (www.akhe.ru) é sóbria, limpa com boas imagens, excelentes fotografias dos espectáculos, textos curtos (com algumas incorrecções na versão inglesa), de fácil navegação e alguma informalidade (como a página sem conteúdo, onde o único texto é "Here text's supposed to be sent by Vadik:-)" [sic].

0 grupo, com uma maioria de membros nascidos na década de 60 em S. Petersburgo, é criado em 1989 e autodenomina-se Teatro de Engenharia Russo - um teatro físico em que a palavra é posta de lado e os enredos são contados a partir de propostas cénicas inovadoras.

0 prazer que se tem ao percorrer este sítio é o de imaginar que um dia no seu calendário poderá constar uma cidade perto de nós e, assim, se possa ver ao vivo o que nos aliciou on-line.

0 Tiny Ninja Theater (www.tinyninjatheater.com) surgiu em 1999 quando o seu director, Dov Weinstein, se lembrou de utilizar pequenos bonecos de plástico com figuras de ninja como actores. 0 primeiro espectáculo da companhia, em 2000, foi imediatamente galardoado com o Prémio de Excelência para Inovação e Originalidade' com a apresentação do clássico Macbeth.

Neste sítio, construído com humor e onde os bonecos são tratados como verdadeiros actores, temos acesso à ficha técnica dos espectáculos, às críticas, a uma loja com artigos criados a partir dos bonecos. Temos ainda possibilidade de o próprio navegador poder "encenar" um espectáculo através da escolha dum cenário, de alguns actores e da sua colocação em cena. 